\title{
PARTISIPASI ORANG TUA TERHADAP PERLINDUNGAN ANAK SEBAGAI SUATU BENTUK PERLINDUNGAN HAK ASASI MANUSIA
}

\author{
Cunduk Wasiati
}

Fakultas Hukum Universitas Widya Mataram

Jln.Ndalem Mangkubumen KT III/237, Kadipaten Kraton, Kota Yogyakarta,

Daerah Istemewa Yogyakarta 55132

\begin{abstract}
Abstrak
Dewasa ini bangsa Indonesia dihadapkan dengan bentuk perlindungan yang tidak berjalan dengan baik, hal ini dapat merusak masa depan negara Indonesia. Bangsa Indonesia sebenarnya sadar anak adalah sebagai generasi penerus bangsa dan juga sebaga regenerasi dari masyarakat. Sangat sedih melihat orang tua tidak memberikan perlindungan anak kepada anak-anaknya. Anak-anak dipukuli, diperkosa, ditelantarkan dan lain sebagainya. Apakah orang tua tidak sadar jika itu melanggar hak asasi manusia? Tulisan ini mencoba membahas hal itu dengan rumusan masalah apakah perlindungan anak sebagai bagian dari hak asasi manusia? Bagaimana partsipasi orang tua terhadap perlindungan anak? serta menawarkan konsep perlindungan anak berkelanjutan. Tulisan ini menggunakan penelitian yuridis normatif. Penulis mencoba menjawab pertanyaan tersebut: Perlindungan Anak merupakan bagian dari Hak Asasi Manusia. Partispasi orang tua terhadap perlindungan anak dapat ditemui dalam Undang-Undag Nomor 35 Tahun 2014 tentang Perubahan Atas Undang-Undang Nomor 23 Tahun 2002 tentang Perlindungan Anak serta Undang-Undang Nomor 1 Tahun 1974 Tentang Perkawinan. Konsep perlindungan anak yang berkelanjutan sangat dibuthkan didalam mengawal pelindungan anak, konsep ini memberikan ketegasan bahwa perlindungan anak harus dioptimalkan.
\end{abstract}

Kata Kunci: Anak, Hak Asasi Manusia, Orang Tua, Perlindungan.

\begin{abstract}
Today the Indonesian people are faced with a form of protection that is not going well, it is equally damaging the future of the Indonesian state. We are actually aware of the child is as the future generation and also sebaga regeneration of society. Very sad to see parents do not provide child protection to their children. Children are beaten, raped, neglected and so forth. What parents do not realize if it violates human rights? This paper attempts to discuss it with the formulation of the problem is the protection of children as part of human rights? How's participation of parents of child protection? as well as offering the concept of sustainable child protection. This paper uses normative juridical research. The author tries to answer the question: Child Protection is part of the of Human Rights. Participation of parents about child protection can be found in Law No. 35 of 2014 on the Amendment of Act No. 23 of 2002 on Child Protection and Law No. 1 of 1974 About Marriage. The concept of sustainable child protection very need to escorting the protection of children, the concept is made clear that child protection must be optimized.
\end{abstract}

Key words: Child, Human Rights, Parent, Protection.

\section{A. Pendahuluan}

Dewasa ini kondisi perlindungan anak sangat menyedihkan, dimana dengan kemajuan teknologi, akses terhadap pelanggaran perlindungan semakin cepat sampai untuk dilihat ataupun dibaca. Lihat saja media televisi yang semakin canggih, dahulu berita di televisi cuma bisa ditonton di monitor televisi, namun dengan 
perkembangan zaman yang sangat cepat, informasi ini bisa dilihat di media handphone pintar. Selain itu untuk membaca kasus perlindungan anak di media massa yang bisanya bisa kit abaca di kran, bulletin ataupun majalah mingguan yang terbit dalam jangka waktu seminggu, perbulan, pertriwulan ataupun persemester sekarang sudah bisa kita akses di handphone pintar juga, selain itu jaringan komunikasi untuk menyampaikan berita tentang pelanggaran perlindungan anak juga semakin bertmabah canggih, lihat saja sekarang semua berita tentang perkembangan perlindungan anak bisa dilihat media sosial semacam facebook, tweeter, path, line, waatshap, instagram ataupun media sosial yang lainnya.

Informasi berita yang tersaji pada hari ini memperlihatkan perlindungan anak yang semakin miris, dimana semakin banyak pihak yang tidak mau lagi berpartisipasi terhadap perlindungan anak, karena perlindungan anak ini merupakan salah satu bagian dari hak asasi manusia. Tetapi dengan yang kita saksikan sekarang sangat mengurut hati nurani para pemerhati anak, karena kenyataan yang dicita-citakan untuk perlindungan anak tidak sesuai dengan yang semestinya.

Berbicara mengenai anak adalah sangat penting karena anak merupakan potensi nasib manusia hari mendatang, dialah yang ikut berperan menentukan sejarah bangsa sekaligus cermin sikap hidup bangsa pada masa mendatang ${ }^{1}$. Karena berbicara anak maka kita akan berbicara tentang pembangunan hukum juga, karena anak lah yang nantinya akan membangun hukum di Indonesia ini saat mereka dewasa dan memiliki pengetahuan yang cukup terkait menciptakan suatu peraturan. Ini semua disebabkan bahwa pembangunan hukum telah menjadi kebutuhan yang tidak dapat dielakkan oleh banyak negara. Kemerdekaan dan pembangunan telah mendorong negara untuk mengadakan penataan kembali tatanan masyarakat mereka, baik di bidang politik, ekonomi, maupun bidang sosial. Proses untuk merubah tata jajahan menuju masyarakat merdeka yang sibuk pembangunan mengharuskan mereka untuk melaksanakan pembangunan hukum² ${ }^{2}$.

Maka dari pada itu pemerintah telah membentuk suatu pengaturan perlindungan anak yang membahas segala lini perlindungan anak dan memperbaharui peraturan yang berkaitan tentang anak pada tahun-tahun yang lampau, dimana perlindungan anak ini sendiri berdiri sendiri pada tahun 2002 yaitu Undang-Undang

${ }^{1}$ Wagiati Soeteddjo dan Melani, 2011, Hukum Pidana Anak, Bandung, Refika Aditama, hlm. 5

2 Abdul Garuda Hakim Nusantara dan Nasroen Yasabari, 1980, Beberapa Pembangunan Hukum Di Indonesia, Bandung, Alumni, hlm. 1. 
Nomor 23 Tahun 2002 Tentang Perlindungan Anak yang pada tahun 2014 dirubah kembali dengan Undang-Undang Nomor 35 Tahun 2014 tentang Perubahan Atas Undang-Undang Nomor 23 Tahun 2002 Tentang Perlindungan Anak, yang kemungkinan akan dirubah lagi setelah Presiden Republik Indonesia yaitu Joko Widodo mengeluarkan Peraturan Pemerintah Pengganti Undang-Undang Nomor 1 Tahun 2016 Tentang Kebiri.

Sebagai suatu bidang kajian, hukum perlindungan anak telah dikenal di beberapa negara barat, melalui tulisan-tulisan khusus tentang masalah tersebut. Bagi negara-negara yang mengenal kodifikasi seperti di negeri Belanda ada usaha-usaha penyesuaian di bidang hukum, dengan cara meninjau kembali pasal-pasal yang terdapat dalam kitab-kitab hukum, baik public maupun perdata, pasal-pasal yang merugikan bagi kehidupan anak, seperti yang dilaksanakan oleh suatu panitia pimpinan Wiarda pada tahun 1965-1971. Walaupun demikian hal ini tidak berate bahwa bagi negara yang tidak mengenal sistem hukum seperti tersebut di muka, tidak mengenal hukum yang berwawasan pada kepentingan anak/remaja. Sebagai contoh di Indonesia aspek-aspek hukum perlindungan anak dapat dietemui dalam berbagai ketentuan hukum, baik tertulis maupun hukum adat, hanya tolak ukur yang dipergunakan mungkin berbeda. Tolak ukur ini tentunya bagi tiap masyarakat dan negara akan lain, karena adanya pengaruh berbagai macam faktor lain nilai budaya, serta agama, dan falsafah negara masing-masing ${ }^{3}$.

Anak dilahirkan merdeka, tidak boleh dilenyapkan atau dihilangkan, tetapi kemerdekaan anak harus dilindungi dan diperluas dalam hal mendapatkan hak atas hidup dan hak perlindungan baik dari rang tua, keluarga, masyarakat, bangsa dan negara. Perlindungan anak tersebut berkautan erat untuk mendapatkan hak asasi mutlak dan mendasar yang tidak boleh dikurangi satupun atau asasi mutlak dan mendasar yang tidak boleh dikurangi satupun atau mengorbankan hak mutlak lainnya untuk mendapatkan hak lainnya, sehingga anak tersebut akan mendapatkan hakhaknya sebagai manusia seutuhnya bila ia menginjak dewasa. Dengan demikan, bila anak telah menjadi dewasa, maka anak tersebut akan mengetahui dan memahami

\footnotetext{
${ }^{3}$ Irma Setyowati Soemitro, 1990, Aspek Hukum Perlindungan Anak, Jakarta, Bumi Aksara, hlm. $9-10$.
} 
menganai apa yang menjadi dan kewajiban baik terhadap keluarga, masyarakat, banga dan negara ${ }^{4}$.

Hak asasi anak adalah hak asasi manusia plus dalam arti kata harus mendapatkan perhatian khusus dalam memberikan perlindungan, agar anak yang baru lahir, tumbuh dan berkembang mendapat hak asasi manusia secara utuh. Hak asasi manusia meliputi semua yang dibutuhkan untuk pembangunan manusia seutuhnya dan hukum positif mendukung pranata sosial yang dibuthkan untuk pembangunan seutuhnya tersebut. Pembangunan manusia seutuhnya melalui suatu proses evolusi yang berkesinambungan yang disebabkan oleh kesadaran diri manusia, yang lebih penting dari proses itu sendiri adalah suatu aktualisasi dari potensi manusia seperti yang terdapat pada individu dan komunitasnya. Hak asasi manusia adalah hak dari setiap manusia yang dibuthkan untuk pembangunan manusia seutuhnya. Hukum positif adalah pranata sosial yang dibutuhkan oleh semua manusia untuk melaksanakan hak-hak asasi manusia, hak asasi manusia adalah dasar hukum positif. Penegak hukum digunakan secara efektif, bila ada pelanggaran hak asasi manusia dalam pembangunan atau pembangunan yang dilaksanakan telah bertentangan dengan hak asasi manusia. Manusia/anak telah dirampas hak asasinya dengan digunakan sebagai alat pembangunan untuk kepentingan dirinya atau kelompok yang berkuasa ${ }^{5}$.

Pasal 1 angka 2 Undang-Undang Perlindungan Anak menyatakan bahwa perlindungan anak adalah segala kegiatan untuk menjamin dan melindungi anak dan hak-haknya agar dapat hidup, tumbuh, berkembang dan berpartisipasi secara optimal sesuai dengan harkat dan martabat kemanusiaan, serta mendapat perlindungan dari kekerasan dan diksriminasi. Dimana perlindungan ini juga harus dilindungi oleh keluarga, maksud dari keluarga menurut Pasal 1 angka 3 Undang-Undang Perlindungan Anak menyatakan bahwa keluarga adalah unit terkecil dalam masyarakat yang terdiri dari suami istri dan anaknya, atau ayah anaknya, atau ibu dan anaknya, atau keluarga sedarah dalam garis lurus ke atas atau ke bawah sampai dengan derajat ke lima. Sedangkan untuk orang tua sendiri dijelaskan dalam Pasal 1 angka 4 Undang-Undang Perlindungan Anak menyatakan bahwa orang tua adalah ayah/ibu kandung, atau ayah dan/atau ibu tiri, ayah dan/atau angkat. Lebih lanjut

${ }^{4}$ R. Abdussalam, 2007, Hukum Perlindungan Anak, Jakarta, Restu Agung, hlm. 10-11.

${ }^{5}$ R. Abdussalam dan Adri Desasfuryanto, 2007, Hukum Perlindungan Anak, Jakarta, PTIK, hlm. 13. 
Pasal 1 angka a2 Undang-Undang Perlindungan Anak menyatakan hak anak adalah bagian dari hak asasi manusia yang wajib dijamin, dilindungi, dan dipenuhi oleh orang tua dan lainnya.

Lebih lanjut partsipasi orang tua terhadap perlindungan anak diatur dalam Pasal 20 Undang-Undang Perlindungan anak yang menyatakan bahwa negara, Pemerintah, Pemerintah Daerah, Masyarakat, Keluarga, dan Orang Tua atau wali berkewajiban dan bertanggung jawab terhadap penyelenggaraan Perlindungan Anak. Lebih dalam lagi didalam Pasal 23 ayat (1) menyatakan juga bahwa Negara, Pemerintah, dan Pemerintah Daerah menjamin perlindungan, pemeliharaan, dan kesejahteraan anak dengan memperhatikan hak dan kewajiban Orang Tua, wali, atau orang lain yang secara hukum bertanggung jawab terhadap anak. Tetapi mengapa selalu saja ada orang tua yang tega tidak memenuhi perlindungan anaknya?

Lihat saja kasus-kasus pembuangan bayi oleh orang tua kandungnya, dimana bayi yang terbuang atau sengaja dibuang itu akibat dari hasil hubungan tidak dibawah pernikahan. Kemudian ada juga orang tua yang tega menjual anaknya akibat desakan kebutuhan ekonomi kehidupan pada saat ini. Ada pula orang tua yang menyuruh anaknya mengamen ataupun mengemis untuk memenuhi kehidupan ekonomi keluarga, sehingga mengabaikan keselamatan dan pendidikan anak. Selain itu ada juga orang tua yang berani memperkerjakan anaknya dengan secara brutal, melebih kapasitas beban anak bekerja. Itu hanya sedikit contoh lalainya orang tua dalam rangka ikut berpartispasi dalm perlindungan anak.

Atas penjelasan yang telah dijelaskan sebelumnya maka penulis mencoba untuk membahas bagaimana kedudukan perlindungan anak di mata hak asasi manusia? Bagaimana partispasi orang tua dalam rangka memenuhi perlindungan anak? menggagas konsep perlindungan anak yang berkelanjutan dalam rangka menjamin perlindungan anak di Indonesia.

Penelitian karya ilmiah ini, berjenis penelitian hukum normatif yuridis normatif $)^{6}$. Pada penelitian yuridis normatif penelitian ini difokuskan untuk mengkaji dan meneliti partisipasi orang tua di dalam perlindungan anak yang berkelanjutan. Penelitian ini akan melihat nilai ilmiah suatu pembahasan dan pemecahan masalah terhadap legal issue dengan cara pendekatan-pendekatan (approach) yang digunakan, antara lain:

${ }^{6}$ Zainuddin Ali, 2010, Metode Penelitian Hukum, Jakarta, Sinar Grafika, hlm. 30. 
1. Pendekatan Perundang-undangan (Statute Approach). Pendekatan perundangundangan merupakan suatu hal yang mutlak dalam penelitian yuridis normatif, karena yang akan diteliti adalah berbagai aturan hukum yang menjadi fokus sekaligus tema sentral suatu penelitian. Pendekatan perundang-undangan dilakukan dengan menelaah semua undang-undang dan regulasi yang bersangkut paut dengan isu hukum yang sedang ditangani ${ }^{7}$ yaitu isu partisipasi orang tua di dalam perlindungan anak.

2. Pendekatan Historis (Historical Approach). Pendekatan historis dilakukan dalam kerangka pelacakan sejarah lembaga hukum dari waktu ke waktu. Pendekatan ini sangat membantu peneliti untuk memahami filosofi dari aturan hukum dari waktu ke waktu. Disamping itu, melallui pendekatan demikian penelitian ini juga dapat memahami perubahan dan perkembangan filosofi yang melandasi aturan hukum tersebut. $^{8} \quad$ Penelitian normatif yang menggunakan pendekatan sejarah memungkinkan seorang peneliti untuk memahami hukum secara lebih mendalam tentang suatu pengaturan hukum tertentu sehingga dapat memperkecil kekeliruan, baik dalam pemahaman maupun penerapan suatu lembaga atau ketentuan hukum tertentu ${ }^{9}$ terhadap partisipasi orang tua di dalam perlindungan anak

3. Pendekatan Kasus (Case Approach). Berbeda dengan penelitian sosial ${ }^{10}$, pendekatan kasus (case approach), dalam penelitian normatif bertujuan untuk mempelajari penerapan norma-norma atau kaidah hukum yang dilakukan dalam praktik hukum. ${ }^{11}$ Pendekatan kasus (case approach) tidak sama dengan studi kasus (case study). Dalam pendekatan kasus beberapa kasus ditelaah untuk dijadikan referensi bagi suatu isu hukum. Sedangkan studi kasus (case study), adalah suatu studi terhadap kasus-kasus tertentu dilihat dari berbagai aspek hukum perlindungan anak.

Teori yang dipakai dalam tulisan ini adalah teori Hak Asasi Manusia. Ada beberapa teori yang penting dan relevan dengan persoalan Hak Asasi Manusia,

7 Johnny Ibrahim, 2006, Teori dan Metodologi Penelitian Hukum Normatif, Jawa Timur, Bayu Media Publishing, hlm. 302.

${ }^{8}$ Ibid, hlm 126.

${ }_{9}^{9}$ Satjipto Raharjo, 1986, Ilmu Hukum, Bandung, Alumni Bandung, hlm 332.

${ }^{10}$ Marnasse Malo dan Sri Trisnongtias menjelaskan bahwa Tujuan pokok dari Penelitian Sosial (yang tentunya bersifat ilmiah), adalah menjelaskan gejala-gejala sosial yang ada dalam suatu masyarakat. Marnasse Malo dan Sri Trisnongtias, 1997, Metode Penelitian Masyarakat, Jakarta, Pusat Antara Universitas Ilmu-Ilmu Sosial Unversitas Indonesia, hlm. 19.

${ }^{11}$ Johnny Ibrahim, Op.cit, hal 321. 
antara lain, yaitu: teori hak-hak kodrati (natural rights theory), teori positivisme (positivist theory) dan teori relativisme budaya (cultural relativist theory). Menurut teori hak-hak kodrati, Hak Asasi Manusia adalah hak-hak yang dimiliki oleh semua orang setiap saat dan di semua tempat oleh karena manusia dilahirkan sebagai manusia. Hak-hak tersebut termasuk hak untuk hidup, kebebasan dan harta kekayaan seperti yang diajukan oleh John Locke. Pengakuan tidak diperlukan bagi Hak Asasi Manusia, baik dari pemerintah atau dari suatu sistem hukum, karena Hak Asasi Manusia bersifat universal. Berdasarkan alasan ini, sumber Hak Asasi Manusia sesungguhnya sematamata berasal dari manusia ${ }^{12}$. Teori positivisme secara tegas menolak pandangan teori hak-hak kodrati. Keberatan utama teori ini adalah karena hak-hak kodrati sumbernya dianggap tidak jelas. Menurut positivisme suatu hak mestilah berasal dari sumber yang jelas, seperti dari peraturan perundang-undangan atau konstitusi yang dibuat oleh negara. Dengan perkataan lain, jika pendukung hak-hak kodrati menurunkan gagasan mereka tentang hak itu dari Tuhan, nalar atau pengandaian moral yang a priori, kaum positivis berpendapat bahwa eksistensi hak hanya dapat diturunkan dari hukum negara ${ }^{13}$. Keberatan lainnya terhadap teori hak-hak kodrati berasal dari teori relativisme budaya (cultural relativist theory) yang memandang teori hak-hak kodrati dan penekanannya pada universalitas sebagai suatu pemaksaan atas suatu budaya terhadap budaya yang lain yang diberi nama imperalisme budaya (cultural imperalism $)^{14}$.

\section{B. Telaah Konsep}

Perlindungan hukum menjadi sangat penting karena hal tersebut merupakan unsur yang harus ada dalam suatu negara hukum. Perlindungan hukum merupakan segala upaya yang dapat menjamin adanya kepastian hukum, sehingga dapat memberikan perlindungan hukum kepada pihak-pihak yang bersangkutan atau yang

12 Todung Mulya Lubis, 1993, In search of Human Rights Legal-Political Dilemmas of Indonesia's New Order, 1966-1990, S.J.D Dissertaion, (Berkeley: Boalt Hlml Law School - University of California, 1990) didalam Satya Arinanto, 2001, Bahan Bacaan Politik Hukum 2, Jakarta, Program Pasca Sarjana FHUI, hlm. 13.

13 Scott Davidson, 1994, Hak Asasi Manusia, Sejarah, Teori dan Praktek dalam Pergaulan Internasional, Jakarta, Grafiti, hlm. 40.

${ }^{14}$ Ibid, hlm. 19. 
melakukan tindakan hukum, ${ }^{15}$ Menurut Satijipto Raharjo dikutip dalam buku penerapan teori hukum pada penelitian tesis dan disertasi; perlindungan hukum adalah memberikan pengayoman terhadap hak asasi manusia (HAM) yang dirugikan orang lain dan perlindungan itu diberikan kepada masyarakat agar dapat dinikmati semua hak-hak yang diberikan oleh hukum ${ }^{16}$

Menurut Philipus M. Hadjon ${ }^{17}$ berpendapat bahwa Perlindungan Hukum bagi rakyat sebagai tindakan pemerintah pemerintah yang bersifat preventif dan represif perlindungan hukum yang preventif bertujuan untuk mencegah terjadinnya sengketa yang mengarahkan tindakan pemerintah bersikap hati hati dalam mengambil keputusan berdasarkan diskresi dan perlindungan yang represif bertujuan untuk menyelesaikan sengketa. Itu artinya perlindungan akan harkat dan martabat, serta pengakuan terhadap hak-hak asasi manusia yang dimiliki oleh subyek hukum berdasarkan ketentuan hukum dari kesewenangan. Menurut CST Kansil Perlindungan Hukum adalah berbagai upaya hukum yang harus diberikan oleh aparat penegak hukum untuk memberikan rasa aman, baik secara pikiran maupun fisik dari gangguan dan berbagai ancaman dari pihak manapun.

\section{Metode Penelitian}

Secara khusus menurut jenis, sifat dan tujuannya suatu penelitian hukum dibedakan menjadi dua penelitian yuridis normatif dan penelitian yuridis empiris. Dalam penelitian yang dilakukan penulis saat ini digunakan penelitian yang bersifat normatif atau yuridis normatif " Metode penelitian ini yang digunakan oleh penulis dalam penulisan ini adalah penelitian hukum normatif, yaitu penelitian hukum doktriner, juga disebut sebagai penelitian perpustakaan atau studi dokumen. Disebut penelitian hukum doktriner, karena penelitian ini dilakukan atau ditujukan hanya pada peraturan-peraturan yang tertulis atau bahan-bahan hukum yang lain, sebagai penelitian perpustakaan atau studi dokumen disebabkan penelitian ini banyak

15 Setiono, Rule of Law (Supremasi Hukum), (Surakarta: Magister Ilmu Hukum Program Pasca Sarjana Universitas Sebelas Maret, 2004), hlm. 3, dikutip dalam (http://digilib.unila.ac.id/6225/13/BAB\%20II.pdf). Diakses 5 oktober 2015.

${ }^{16}$ H. Salim HS dan Erlies Septiana N, Penerapan teori bukum pada Penelitian Tesis dan Disertasi, Rajawali Pers, Jakarta, 2014, cet 3, hlm 262.

${ }_{17}$ Philipus M. Hadjon, Perlindungan bukum bagi rakyat Indonesia, sebuah studi tentang prinsip prinsip penanganan oleh pengadilan dalam lingkungan peradilan umum dan pembentukan peradilan administrasi, Fakultas Hukum Universitas Airlangga, Surabaya, 1985, hlm 2. 
dilakukan terhadap data yang bersifat sekunder yang ada di perpustakaan ${ }^{18}$. Sehubungan dengan tipe penelitiannya yuridis normatif maka pendekatan yang digunakan adalah pendekatan hukum yang berlaku di Indonesia (hukum positif). Suatu analisis pada hakekatnya menekankan pada metode deduktif sebagai pegangan utama, dan metode induktif sebagai tata kerja penunjang.analisis normatif mempergunakan bahan-bahan kepustakaan sebagai sumber data penelitiannya. ${ }^{19}$

\section{Pembahasan}

\section{Kedudukan Perlindungan Anak Dalam Kaca Mata Hak Asasi Manusia}

Prinsip fundamental dari suatu keadilan adalah pengakuan bahwa semua manusia itu memiliki martabat yang sama. Di samping itu memiliki hak-hak dan kewajiban-kewajiban yang sama pula. Persamaan fundamental tersebut sejalan dengan sikap tidak membedakan jenis kelamin, suku, agama atau status sosial seseorang $^{20}$. Hak-hak yang paling fundamental itu adalah aspek-aspek kodrat manusia atau kemanusiaan itu sendiri. Kemanusiaan setiap manusia atau kemanusiaan itu sendiri. Kemanusiaan setiap manusia merupakan ide yang luhur dari Sang Pencipta yang menginginkan setiap orang berkembang dan mencapai kesempurnaanya sebagai manusia. Karena iu setiap manusia harus dapat mengembangkan diri sedemikian rupa sehingga dapat terus berkembang secara leluasa. Pengembangan diri ini dipertanggungjawabkan kepada Tuhan, asal dan tujuan hidup manusia. Semua hak yang berakar dalam kodratnya sebagai manusia adalah hak-hak yang lahir bersama dengan eksistensi manusia dan merupakan konsekuensi hakiki dari kodratnya. Itulah sebabnya mengapa Hak Asasi Manusia bersifat universal. Di mana ada manusia di situ ada Hak Asasi Manusia yang harus dihargai dan dijunjung tinggi ${ }^{21}$.

Pengertian umum dari Hak Asasi Manusia seperti dikemukakan oleh Jan Marttenson dari Komisi Hak Asasi Manusia PBB dapat disimpulkan dalam kalimat sebagai berikut "Human Right could be generally defined as those rights which are inherent in our

${ }^{18}$ Bambang Waluyo, Penelitian Hukum Dalam Praktek, Jakarta, Sinar Grafika, 2008,hlm 14

19 Amirudin, Zainal Asikin, Pengantar Metode Penelitian Hukum, Jakarta, Raja Grafindo, 2012, hlm. 16

${ }^{20}$ Krisna Harahap, 2003, HAM dan Upaya Penegakannya Di Indonesia, Jakarta, PT Grafitri Budi Utama, hlm. 1.

${ }_{21}$ Gunawan Setiadirdja, 1993, Hak-hak Asasi Manusia Berdasarkan Ideologi Pancasila, Jakarta, Penerbit Kanisius, hlm. 75. 
nature and without which we can not live as buman being". Dengan demikian, menurut Jan Martenson, Hak Asasi Manusia itu merupakan hak yang melekat pada sifat manusia yang tanpa tersebut, manusia mustahil dapat hidup sebagai manusia. Berdasarkan definisi tersebut, kita menemukan bahwa pengertian mengenai Hak Asasi Manusia itu sangtlah luas. Namun demikian, yang melandasi lahirnya Hak Asasi Manusia dapat digolongkan dalam tiga macam konsep: 1) bersumber dari hukum kodrat (natural law); 2) Merupakan karunia Tuhan Yang Maha Esa; 3) Merupakan hak diatur dalam peraturan (legal rights), dalam pada itu, kepustakaan tentang Hak Asasi Manusia membaginya dalam hak-hak dasar: a) yang bersifat klasik (de klassieke gronrechten), b) yang bersifat sosial (de sociale gronrechten) ${ }^{22}$.

Dalam upaya penegakannya, Hak Asasi Manusia mempunyai beberapa konsep dasar, yaitu bahawa Hak Asasi Manusia merupakan jembatan menuju perilaku beradab yang diciptakan dan diakui oleh masyarakat dunia, yang merupakan bagian dari undang-undang dan kebijkan negara di dunia, telah dimodifikasi ke dalam hukum Internasional dan diakui oleh pengadilan internasional. Kemudian berada di atas kepentingan semua golongan, karena merupakan cara bagi semua orang "di seluruh dunia", bai yang lemah maupun yang kuat, untuk memberi pembenaran terhadap kebutuhan dan aspirasi mereka. Serta tidak bergantung pada kesamaan agama, filsafat konsep manusia, melainkan bergantung pada sejauh mana kita saling berbagi komitmen mengenai apa yang dibutuhkan untuk menciptakan dunia yang beradab dan juga Hak Asasi Manusia merupakan "asas keadilan dan moral” yang telah diterima atau dimiliki bersama oleh setiap orang, "semata karena kita manusia". Hal ini berarti bahwa setiap orang berhak menikmati Hak Asasi Manusia yang dimilikinya, sementara polisi berkewajiban untuk menghormati dan meliondungi Hak-Hak Asasi Manusia setiap orang ${ }^{23}$.

Sebagai bagian dari masyarakat Internasional Pemerintah Republik Indonesia, pada tanggal 26 Januari 1990 di New York menandatangani pengesahan Convention on The Rights of The Child. Kemudian melalui Keputusan Presiden Republik Indonesia Nomor 36 Tahun 1990 tentang Pengesahan Convention on The Rights of The Child (Konvensi tentang Hak-Hak Anak), Indnesia mengikatkan diri pada konvensi ini. Adapun beberapa butir penting dalam Konvensi Perserikatan Bangsa-Bangsa tentang

22 Krisna Harahap, Op.cit, hlm. 2.

${ }^{23}$ Kepolisan Republik Indonesia, 2006, Buku Panduan Tentang Hak. Asasi Manusia Untuk. Anggota Polri, Jakarta, hlm. 13. 
hak-hak anak, adalah: 1) menghormati dan menjamin hak-hak anak, tanpa diskriminasi dalam bentuk apapun (Pasal 1); 2) Negara peserta akan menjamin langkah-langkah tidak ada diskriminasi itu (Pasal 2); 3) kepentingan anak akan menjadi pertimbangan utama dalam semua tindakan yang dilakukan oleh lembaga pemerintah, swasta, lembaga, peradilan dan legislatif, menyangkut anak (Pasal 3 ayat 1); 4) menjamin adanya perlindungan danb perawatan kesejahteraan anak, untuk itu harus diambil tindakan legislatif dan administratif yang layak mengenai hak dan kewajiban orang tua, wali dan sebagainya (Pasal 3 ayat 2); 5) menjamin agar semua instansi menyesuaikan diri dengan norma yang ditetapkan oleh lembaga yang berwenang dalam keselamatan dan kesehatan anak (Pasal 4); 6) mengambil langkah legislatif, administratif dan langkah lainnya untuk pelaksanaanhak-hak yang diakui dalam konvensi; 7) sejak lahirnya seseorang anak berhak atas nama pendaftaran kelahiran, dan kewarganegaraan (Pasal 7 ayat 1); 8) menghormati hak anak untuk mempertahankan identitasnya termasuk kewarganegaraannya, nama dan hubungan keluarga sebagaimana yang diakui oleh undang-undang (Pasal 8 ayat 1); 9) Jamninan bahwa anak tidak akan dipisahkan dengan orang tuanya, kecuali demi kepentingan anak itu sendiri; 10) Jaminan untuk penyatuan kembali keluarga, dengan membolehkan keluar atau masuk kembali ke negara peserta (repratiasi) diatur dalam pasal 10; 11) memberantas penyerahan anak ke luar negeri (Pasal 11); 12) menjamin pandangan anak sesuai dengan usia dan kematangan anak; 13) hak anak untuk menyatakan pendapat secara bebas; 14) hak anak atas kemerdekaan berpikir (Pasal 14); 15) hak anak atas kemerdekaan berkumpul (Pasal 15); 16) jaminan Pribadi Anak (Pasal 16); 17) menjamin hak anak memperoleh informasi (Pasal 17); 18) tanggungjawab orang tua membesarkan anak (Pasal 18); 19) Langkah-langkah legislasi, administrasi, sosial dan pendidikan untuk melindungi anak dari kekerasan fisik, mental dan penyalahgunaan, penelantaran, atau perlakuan salah, pelukan (injury) atau eksploitasi termasuk penyalahgunaan seksual (Pasal 19); 20) perlindungan bagi anak yang kehilangan orangtuanya (Pasal 20); 21) upaya adopsi harus dilakukan demi kepentingan anak (Pasal 21); 22) langkah-langkah yang layak bagi anak pengungsian (Pasal 22); 23) menjamin martabat anak yang cacat fisik dan mental (Pasal 23); 24) mengakui hak anak untuk menikmati norma kesehatan tertinggi dan fasilitas perawatan serta pemulihan kesehatan (Pasal 24); 25) hak evaluasi secara berkala atas perawatan kesehatan jasmani dan rohani (Pasal 25); 26) hak anak atas jaminan sosial 
(Pasal 26); 27) hak anak atas kehidupan yang layak (Pasal 27); 28) hak anak atas pendidikan (Pasal 28); 29) Hak anak atas arah pendidikan yang baik (Pasal 29); 30) hak anak minoritas atas budaya dan agamanya sendiri (Pasal 30); 31) hak anak atas beristirahat, bersantai, bermain, dan rekreasi (Pasal 31); 32) kewajiban melindungi anak dari eksploitasi (Pasal 32); 33) perlindungan anak dari bat terlarang (Pasal 33); 34) melindungi anak dari penyalahgunaan seksual (Pasal 34); 35) mencegah penculikan, penjualan, atau jual beli anak (Pasal 35); 36) melindungi anak dari segala bentuk eksploitasi (Pasal 36); 37) snsk tidak boleh disiksa dan dirampas kemerdekaannya (Pasal 37); 38) negara peserta menghormati hukum kemanusiaan internasional mengenai anak (Pasal 38); 39) meningkatkan pemulihan rohani, jasmani, dan penyatuan kembali anak pada masyarakat bagi anak yang menjadi korban setiap bentuk pelanggaran hak anak dan kejahatan (Pasal 39) dan 40) mengakui hak anak yang disangka melanggar hukum (Pasal 40) ${ }^{24}$.

Indonesia sendiri sebagai negara hukum, mengatur Hak Asasi Manusia di dalam Undnag-Undang Nomor 39 Tahun 199 Tentang Hak Asasi Manusia. Menurut Masyur Effendi, hak-hak yang tercantum dalam undang-undang ini terdiri atas ${ }^{25}$ :

1) Hak untuk hidup, setiap orang berhak untuk hidup, mempertahankan hidup, meningkatkan taraf kehidupannya, hidup tenteram, damai, bahagia, sejahtera lahir dan batin serta memperoleh lingkungan hidup yang baik dan sehat. Hak berkeluarga untuk melanjutkan keturunan. Setiap orang berhak untuk membentuk keluarga dan melanjutkan keturunan melalui perkawinan yang sah atas kehendak yang bebas;

2) Hak mengembangkan diri, setiap orang berhak untuk memperjuangkan hak pengembangan dirinya, baik secara pribadi maupun kolektif, untuk membangun masyarakat, bangsa dan negaranya;

3) Hak memperoleh keadilan, setiap orang, tanpa diksriminasi, berhak untuk memperoleh keadilan dengan mengajukan permohonan, pengaduan, dan gugatan, baik dalam perkara pidana, perdata, maupun administrasi serta diadili melaui proses peradilan yang bebas dan tidak memihak, sesuai dengan hukum

24 Otong Rosadi, 2004, Hake Anak Bagian Dari HAM, Bandung, Akademika, hlm. 48-50.

${ }^{25}$ H. A. Prayitno dan Trubus Rahardiansah P, 2013, Pendidikan Kadeham, Kebangsaan, Demokrasi dan Hak Asasi Manusia, Menapak Jejak-Jejak Reformasi, Jakarta, Penerbit Universitas Trisakti, hlm. 152154 
acara yang menjamin pemeriksaan secara obyektif oleh hakim yang jujur dan adil untuk memperoleh putusan adil dan benar;

4) Hak atas kebebasan pribadi, setiap orang bebas untuk memilih dan mempunyai keyakinan politik, mengeluarkan pendapat di muka umu, memeluk agama masing-masing, tidak boleh diperbudak, memiliki kewarganegaraan tanpa diskriminasi, bebas bergerak, berpindah dan bertempat tinggal di wilayah Republik Indonesia;

5) Hak atas rasa aman, setiap orang berhak atas perlindungan diri pribadi, keluarga, kehormatan, martabat, hak milik, rasa aman dan tenteram serta perlindungan terhadap ancaman ketakutan untuk berbuat atau tidak berbuat sesuatu;

6) Hak atas kesejahteraan, setiap orang berhak mempunyai milik, baik sendiri maupun bersama-sama dengan orang lain demi pengembangan dirinyam bangsa dan masyarakat dengan cara tidak melanggar hukum serta mendapatkan jaminan sosial yang dibutuhkan, berhak atas pekerjaan, kehidupan yang layak dan berhak mendirikan serikat pekerja demi melindungi dan memperjuangkan kehidupannya;

7) Hak turut serta dalam pemerintahan, setiap warga negara berhak turut serta dalam pemerintahan dengan lansung atau perantaraan wakil yang dipilih secara bebas dan dapat diangkat kembali dalam setiap jabatan pemerintahan;

8) Hak wanita, seorang wanita berhak untuk memilih, dipilih, diangkat dalam jabatan, profesi dan pendidikan sesuai dengan persyaratan dan peraturan perundang-undangan. Di samping itu berhak mendapatkan perlindungan khusus dalam pelaksanaan pekerjaan atau profesinya terhadap hal-hal yang dapat mengancam keselamatan dan atau kesehatannya; dan

9) Hak anak, setiap anak berhak atas perlindungan oleh orang tua, keluarga, masyarakat dan negara serta memperoleh pendidikan, pengajaran dalam rangka pengembangan diri dan tidak dirampas kebebasannya secara melawan hukum.

Atas dasar hal tersebut sudah jelas bahwa perlindungan merupakan bagian dari Hak Asasi Manusia, dan mendapatkan tempat prioritas. Lebih lanjut Rahayu lebih mengkrucutkan hak anak sebagai bagian dari Hak Asasi Manusia yang dilihat 
dari Undang-Undang Perlindungan Anak, yang menyatakan bahwa Undang-Undang Perlindungan Anak lahir sebagai rekasi atas berbagai pelanggaran yang dilakukan oleh berbagai pihak terhadap anak, antara lain seperti: jual beli/perdagangan anak (trafficking), pemaksaan anak untuk bekerja, perusahaan yang mempekerjakan anak, kelompok pemberontak yang memggunakan anak sebagai informan atau sebagai tentara, anak sebagai korban kekerasan seksual, anak sebagai pelaku dalam film porno dan tindakan aparat negara yang mengetahui tentang hak-hak anak. Perlindungan terhdap anak akan dilakukan dengan berbagai aktivitas yang dilakukan oleh negara berdasarkan 4 (empat) prinsip utama, yaitu: 1) prinsip non-diskriminasi; 2) kepentingan terbaik untuk anak; 3) hak untuk hidup, kelansungan hidup, dan perkembangan; 4) penghargaan terhadap anak ${ }^{26}$.

Pada hakikatnya orang tua memiliki hak dan kewajiban yang sangat dominan bagi anak, namun jika orang tua melakukan pelanggaran hak anak maka hukuman yang dijatuhkan juga akan semakin berat. Pelanggaran yang dapat dilakukan orang tua kepada anaknya antara lain: diskriminasi, eksploitasi baik ekonomi maupun seksual, penelantaran, kekejaman, kekerasan dan penganiayaan, ketidakadilan serta perlakuan salah lainnya. Ini juga memberikan penegasan, bahwa pelibatan anak dalam berbagai kegiatan orang dewasa tidak dibenarkan. Anak harus dilindungi untuk tidak dilibatkan dalam kegiatan politik (seperti kampanye), dalam sengketa bersenjata, kerusuhan sosial, serta semua kegiatan yang mengandung unsur kejahatan ${ }^{27}$ kerena itu semua bentuk pelanggaran Hak Asasi Manusia dan menggambarkan kebobrokan negara di masa akan datang.

\section{Partisipasi Orang Tua Dalam Rangka Memenuhi Perlindungan Anak}

Untuk sampai pada pemikiran tentang jaminan hak anak dan perlindungannya,maka terlebih dahulu harus diketahui apa yang menjadi penyebab bahwa hak anak dan perlindungan terabaikan. Setelah melalui penganalisaan terdahulu ternyata bahwa hak anak dan perlindungannya terabaikan akibat dari kurangnya perhatian dari keluarga sebagai masyarakat terkecil juga sebagai akibat dari lingkungan sekitar anak. Oleh karena itu pemikiran tentang jaminan hak anak serta perlindungannya perlu dimulai pada perbaikan pola pembinaan anak dalam

${ }^{26}$ Rahayu, 2012, Hukum Hak Asasi Manusia (HAM), Semarang, Badan Penerbit Universitas Diponegoro, hlm. 158-159.

${ }^{27}$ Ibid, blm. 160-161. 
masyarakat kita, dengan mendasarkan kepad kasih sayang dan cinta yang tulus dan murni dari orang tua, yang pada gilirannya akan menumbuhkan rasa kasih sayang dan cinta kepada sesama manusia pada jiwa sang anak di kemudian hari. Beranjak di sini, maka terbentuk suatu masyarakat yang memiliki kesejahteraan, ketentraman dan stabilitas yang tinggi ${ }^{28}$.

Selanjutnya orang tua harus bahwa proses perkembangan anak terdiri dari beberapa fase pertumbuhan yang bisa digolongkan berdasarkan pada parelitas perkembangan jasmani anak dengan perkembangan jiwa anak. Penggolongan tersebut dibagi ke dalam 3 (tiga) fase yaitu ${ }^{29}$ :

1. Fase pertama adalah dimulainya pada usia anak 0 tahun sampai dengan 7 (tujuh) tahun yang bisa disebut sebagai masa anak kecil dan masa perkembangan kemampuan mental, pengembangan fungsi-fungsi tubuh, perkembangan kehidupan emosional, bahasa bayi dan arti bahasa asing bagi anak-anak, masa kritis (trozalter) pertama dan tumbuhnya seksualitas awal pada anak;

2. Fase kedua adalah dimulai pada usia 7 sampai dengan 14 tahun disebut sebagai masa kanak-kanak, dimana dapat digoolongkan ke dalam 2 peride yaitu: a) masa anak sekolah dasar mulai dari usia 7-12 tahun adalah periode intelektual, periode intelektual ini adalah masa belajar awal dimulai dengan memasuki masyarakat di luar keluarga, yaitu lingkungan sekolah kemudian teori pengamatan anak dan hidupnya perasaan, kemauan serta kemampuan anak dalam berbagai macam potensi, namun masih bersifat tersimpan atau masa latensi (masa tersembunyi), b) masa remaja/pra-pubertas atau pubertas awal yang dikenal dengan sebutan perode pueral, pada periode ini terdapat kematangan fungsi jasmaniah ditandai dengan berkembangnya tenaga fisik yang melimpah-limpah yang menyebabkan tingkah laku anak kelihatan kasar, canggung, berandal, kurang sopan, liar dan lain-lain, sejalan dengan berkembangnya fungsi jasmaniah, perkembangan intelektual pun berlansung sangat intensif sehingga minat pada pengetahuan dan pengalaman baru pada dunia luar sabgat besar terutama yang bersifat kongkret, karenanya anak

\footnotetext{
${ }^{28}$ Wagiati, Op.cit, hlm. 54.

${ }^{29}$ Ibid, hlm. 7-8.
} 
puber disebut sebagai fragmatis atau utilitas kecil, di mana minatnya terarah pada kegunaan-kegunaan teknis;

3. Fase ketiga adalah dimulai pada usia 14 sampai 21 tahun, yang dinamakan masa remaja, dalam arti sebenarnya yaitu fase pubertas dan adolescent, di mana terdapat masa penghubung dan masa peralihan dari anak menjadi orang dewasa. Masa remaja atau masa pubertas bisa dibagi dalam 4 (empat) fase, yaitu: a) masa awal pubertas, disebut pula sebagai masa pueral/pubertas, b) masa menentang kedua, fase negatif, trotzalter kedua, periode vemeinung, c) masa pubertas sebenarnya, mulai kurang lebih 14 tahun, masa pubertas pada anak wanita pada umumnya berlansung lebih awal dari pada masa pubertas anak laki-laki, d) fase adolescence, mulai kurang lebih usia 17 tahun sampai sekitar 19 hingga 21 tahun. Fase ketiga ini mencakup point $\mathrm{c}$ dan d di atas, di dalam periode ini terjadi perubahan-perubahan besar. Perubahan besar yang dialami anak membawa pengaruh pad sikap dan tindakan kea rah lebih agresif sehingga pada periode ini banyak anak-anak dalam bertindak dapat digolongkan ke dalam tindakan yang menunjukan ke arah gejala kenakalan anak.

Seperti yang dijelaskan di awal partispasi orang tua di dalam perlindungan anak secara tegas sudah diatur di dalam Undang-Undang Perlindungan Anak. Kebijaksanaan, usaha dan kegiatan yang menjamin terwujudnya perlindungan anak, pertama didasarkan atas pertimbangan bahwa anak-anak merupakan golongan yang rawan dan depedent, di samping itu, karena adanya golongan anak-anak yang mengalami hambatan dalam pertumbuhan dan perkembangannya, baik rohani, jasmani maupun sosial, selain itu dalam pelaksanaan perlindungan anak orang tua harus lah berdasarkan dasar filosofis, dimana pancasila sebagai dasar kegiatan dalam berbagai bidang kehidupan keluarga, bermasyarakat, bernegara, dan berbangsa, dan dasar filosofis pelaksanaan perlindungan anak. Dasar etis, dimana pelaksanaan perlindungan anak harus sesuai dengan etika profesi yang berkaitan, untuk mencegah perilaku menyimpang dalam pelaksanaan kewenagan, kekuasaan dan keuatan dalam pelaksanaan perlindungan anak. Dasar yuridis, pelaksanaan perlindungan anak harus didasarkan pada Undang-Undang Dasar 1945 dan berbagai peraturan perundangundangan lainnya yang berlaku. Penerapan dasar yuridis ini haru secara integratif, 
yaitu penerapan terpadu menyangkut peraturan perundang-undangan dari berbagai bidang hukum yang berkaitan ${ }^{30}$.

Makna yang terdapat didalam Pasal 23 ayat (1) menyatakan bahwa Negara, Pemerintah, dan Pemerintah Daerah menjamin perlindungan, pemeliharaan, dan kesejahteraan anak dengan memperhatikan hak dan kewajiban Orang Tua, wali, atau orang lain yang secara hukum bertanggung jawab terhadap anak, menekankan bahwa setiap yang disebutkan tersebut wajib untuk berpartisipasi dan hal ini berlaku menjadi tanggungjawab. Penekanan terhadap orang tua menurut penulis sangat penting, karena orang tua lah orang yang pertama kali dikenal oleh seorang anak ketika dilahirkan, jadi orang tua tidak boleh macam-macam dengan makna perlindungan anak.

Kesejahteraan anak mempunyai pengaruh positif terhadap orang tua. Perlindungan anak bermanfaat bagi anak dan orang tua, keluarga, masyarakat, pemerintah dan negara. Koordinasi kerja sama kegiatan perlindungan anak perlu dilakukan dalam rangka mencegah ketidakseimbangan kegiatan perlindungan anak secara keseluruhan. Menurut Maidin Gultom bahwa yang mengusahakan perlindungan anak adalah setiap anggota masyarakat sesuai dengan kemampuannya dengan berbagai macam usaha dalam situasi dan kondisi tertentu. Setiap warga negara ikut bertanggung jawab terhadap dilaksanakannya perlindungan anak demi kesejahteraan anak. Kebahagiaan anak merupakan kebahagian bersama, kebahagiaan yang dilindungi adalah kebahagiaan yang melindungi. Tidak ada keresahan pada anak, karena perlindungan anak dilaksanakan dengan baik, anak menjadi sejahtera ${ }^{31}$.

Dalam Undang-Undang Perlindungan Anak kewajiban orang tua terdapat didalam BAB IV bagian keempat yang mengatur tentang Kewajiban dan Tanggung Jawab Orang Tua dan Keluarga. Pengaturan ini telah disempurnakan lagi dengan kehadiran perubahan Undang-Undang Perlindungan Anak. Apabila orang tua ada yang tidak mau berpartisipasi didalam perlindungan anak maka akan menimbulkan sebuah perbuatan pelanggaran hukum, maka Pasal 33 ayat (1) mengatur hal tersebut, yang menyatakan bahwa dalam orang tua dan keluarga anak tidak dapat melaksanakan kewajiban dan tanggung jawab persyaratan dimaksud dalam Pasal 26,

${ }^{30}$ Maidin Gultom, 2012, Perlindungan Hukum Terbadap Anak dan Perempuan, Bandung, Refika Aditama, hlm. 70-71.

${ }^{31}$ Maidin Gultom, 2014, Perlindungan Hukum Terbadap Anak dalam Sistem Peradilan Pidana Anak di Indonesia, Bandung, Refika Aditama, hlm. 48. 
seseorang atau badan hukum yang memenuhi persyaratan dapat ditunjuk sebagai wali dari anak yang bersangkutan ${ }^{32}$.

Jika kita mengacu pada Undang-Undang Perlindungan Anak, maka partispasi orang tua yang diatur didalam aturan tersebut dapat penulis rinci sebagai berikut:

1) Setiap anak berhak untuk diasuh oleh Orang Tuanya sendiri, kecuali jika ada alasan dan/atau aturan hukum yang sah menunjukkan bahwa pemisahan itu adalah demi kepentingan terbaik bagi anak dan merupakan pertimbangan terakhir (Pasal 14 ayat (1));

2) Orang tua berkewajiban dan bertanggung jawab untuk: a) mengasuh, memelihara, mendidik, dan melindungi anak; b) menumbuhkembangkan anak sesuai dengan kemampuan, bakat, dan minatnya; c) mencegah terjadinya perkawinan pada usia Anak, dan d) memberikan pendidikan karakter dan penanaman nilai budi pekerti pada anak (Pasal 26 ayat (1) $)^{33}$;

3) Identitas diri setiap Anak harus diberikan sejak kelahiran (Pasal 27 ayat (1) ) ${ }^{34}$;

4) Orang Tua menjamin Perlindungan Anak dalam memeluk agamanya (Pasal 43 ayat (1);

5) Orang tua bertanggung jawab menjaga kesehatan Anak dan merawat Anak sejak dalam kandungan (Pasal 45 ayat (1) $)^{35}$;

6) Orang Tua wajib melindungi Anak dari perbuatan yang menganggu kesehatan dan tumbuh kembang anak (Pasal 45 B ayat (1));

7) Orang Tua wajib mengusahakan agar anak yang lahir terhindar dari penyakit yang mengancam kelansungan hidup dan/atau menimbulkan kecacatan (Pasal 46);

32 Untuk menjadi Wali dari Anak dilakukan melalui penetapan pengadilan, wali yang ditunjuk harus memiliki kesamaan dengan agama yang dianut anak, wali juga bertanggung jawab terhadap diri anak dan wajib mengelola harta milik anak yang bersangkutan untuk kepentingan terbaik bagi anak, ketentuan lebih lanjut mengenai syarat dan tata cara penunjukan Wali diatur dengan Peraturan Pemerintah.

${ }^{33}$ Dalam hal ketika orang tua tidak ada, maka pengaturannya bisa dilihat dalam 26 ayat (2) yang menyatakan bahwa dalam hal orang tua tidak ada, atau tidak diketahui keberadaannya, atau karena suatu sebab tidak dapat melaksanakan kewajiban dan tanggung jawabnya, kewajiban dan tanggung jawab sebagaimana dimaksud pada ayat (1) dapat beralih kepada keluarga, yang dilaksanakan sesuai dengan ketentuan peraturan perundang-undangan.

${ }^{34}$ Dalam hal anak yang proses akta kelahirannya tidak diketahui dan Orang Tua nya tidak diketahui keberadaannya, pembuatan akta kelahiran untuk anak tersebut didasarkan pada keterangan orang yang menemukannya dan dilengkapi berita acara pemeriksaan kepolisian yang dinyatakan dalam Pasal 27 ayat (4).

35 Dalam hal Orang Tua yang tidak mampu melaksanakan tanggung jawab sebagaimna dimaksud pada ayat (1), Pemerintah dan Pemerintah Daerah wajib memenuhinya. 
8) Orang Tua wajib melindungi Anak dari upaya transplantasi organ tubuhnya untuk pihak lain (Pasal 47 ayat (1) $)^{36}$; dan

9) Orang Tua wajib memberikan kesempatan yang seluas-luasnya kepada Anak untuk memperoleh pendidikan (Pasal 49);

Sebagai anak yang hadir akibat dari sebuah perkawinan maka akan timbullah antara hak dan kewajiban selaku anak. Di antara hak dan kewajiban yang menjadi partispasi orang tua dalam rangka memebuhi hak anak menurut Undang-Undang Nomor 1 Tahun 1974 tentang Perkawinan adalah ${ }^{37}$ :

1) Kedua orang tua wajib memelihara dan mendidik anak-anak mereka sebaikbaiknya (Pasal 45);

2) Anak wajib menghormati orang tua dan menaati kehendak mereka yang baik (Pasal 46);

3) Jika anak tekah dewasa, ia wajib memelihara menurut kemampuannya, orang tua dan keluarga dalam garis lurus ke atas, bila mereka itu memerlukan bantuannya;

4) Orang tua mewakili anak tersebut mengenai segala perbuatan hukum di dalam dan di luar pengadilan (Pasal 47); dan

5) Meskipun orang tua dicabut kekuasaannya, mereka masih tetap berkewajiban untuk memberi biaya pemeliharaan kepada anak tersebut (Pasal 49 ayat (2) ).

\section{Menggagas Konsep Perlindungan Anak Yang Berkelanjutan Dalam Rangka Menjamin Perlindungan Anak Di Indonesia}

Konsep "bekelanjutan" merupakan konsep yang sering digunakan dalam kajian lingkungan dan hukum lingkungan yang dikaitkan dengan pembangunan berkelanjutan (sustainable development) ${ }^{38}$. Berkelanjutan sendiri menurut Kamus Besar Bahasa Indonesia adalah suatu kegiatan yang terus-menerus dan berkesinambungan.

${ }^{36}$ Terkait hal itu, penjelasan lebih lanjut menjelaskan bahwa Orang Tua wajib melindungi Anak dari perbuatan: a) pengambilan organ tubuh anak dan/atau jaringan tubuh anak tanpa memperahtikan kesehatahn anak; b) jual beli organ dan/atau jaringan tubuh anak; dan c) penelitian kesehatan yang menggunakan Anak sebagai objek penelitian tanpa seizing Orang Tua dan tidak mengutamakan kepentingan yang terbaik bagi Anak.

${ }_{37}$ Siska Lis Sulistiani, 2015, Kedudukan Hukum Anak, Hasil Perkawinan Beda Agama Menurut Hukum Positif dan Hukum Islam, Badnung, Refika Aditama, hlm. 17.

38 Yuliandri, Membentuk. Undang-Undang Yang Berkelanjutan, Jurnal Konstitusi, Vol. II No 2, (2009), hlm. 12. 
Terkait hal ini maka konsep berkelanjutan tentu dapat diterapkan di dalam perlindungan, hal ini akan membawa jaminan dan kepastian perlindungan anak yang terus menerus.

Sejatinya gagasan konsep perlindungan anak yang berkelanjutan ini sudah hadir di dalam Undang-Undang Perlindungan Anak, tetapi dalam kenyaataan yang kita lihat di lapangan masih banyak pemenuhan perlindungan anak yang tidak sesuai dengan kadar atau porsinya, sehingga menimbulkan konsep di mata masyarakat, bahwa di Indonesia perlindungan anak tidak diakuai sebagai hak asasi manusia karena tidak ada aturanya, atau bahkan masyarakat mengganggap aturan perlindungan anak sudah ada, tetapi tidak dijalankan, sesuai dengan konsep klasik masyarakat "hukum tumpul ke atas, tajam ke bawah". Jika anak artis atau pejabat yang sering kita temui di layar televisi atau yang sering dibicarakan orang maka haknya terpenuhi, sedangkan bagi anak-anak yang biasa saja atau bahkan tidak mampu haknya tidak terpenuhi, kecuali kasus nya menjadi hot topic di Indonesia.

Undang-Undang Perlindungan Anak menegaskan bahwa pertanggungjawaban orang tua merupakan rangkaian kegiatan yang dilaksanakan secara terus menerus demi terlindunginya hak-hak anak. Rangkain kegiatan tersebut harus berkelanjutan dan terarah guna menjamin pertumbuhan dan perkembangan anak, baik fisik, mental, spiritual, maupun sosial. Tindakan ini dimaksudkan untuk mewujudkan kehidupan terbaik bagi anak yang diharapkan nantinya sebagai penerus generasi bangsa. Upaya perlindungan anak perlu dilaksanakan sedini mungkin, yaitu sejak dari janin dalam kandungan sampai anak berusia delapan belas tahun. Bertitik tolak pada konsep perlindungan anak yang utuh, menyeluruh, dan komprehensif maka Undang-Undang Perlindungan Anak meletakkan kewajiban memberikan perlindungan anak berdasarkan asas-asas ${ }^{39}$ :

a) Asas nondiskriminasi, adalah asas yang tidak membedakan, membatasi, atau mengucilkan anak, baik secara lansung maupun tidak lansung berdasarkan agama, suku, ras, status sosial, status ekonomi budaya, ataupun jenis kelamin yang dapat memengaruhi pemenuhan perlindugan hak-hak anak;

b) Asas kepentingan yang terbaik bagi anak, adalah asas yang menekankan bahwa dalam semua tindakan yang berkaitan dengan anak yang dilakukan

${ }^{39}$ Rika Saraswati, 2015, Hukum Perlindungan Anak Di Indonesia, Bandung, Citra Aditya Bakti, hlm, 24-25. 
oleh pemerintah, masyarakat, ataupun badan legislatif dan yudikatif, kepentingan yang terbaik bagi anak harus menjadi pertimbangan utama;

c) Asas hak untuk hidup, kelansungan hidup, dan perkembangan, adalah asas yang menekankan bahwa setiap anak mempunyai hak untuk hidup dengan aman, tenteram, damai, bahagia, sejahtera lahir dan batin, serta berhak atas pemenuhan kebutuhan dasarnya untuk tumbuh dan berkembang secara layak bagi perkembangan fisik, mental, spiritual, moral, dan sosial anak yang harus dipenuhi oleh pihak-pihak yang disebutkan oleh Undang-Undang Perlindungan Anak memiliki kewajiban dan tanggung jawab untuk itu, yaitu orang tua, masyarakat, dan pemerintahan;

d) Asas penghargaan terhadap pandangan/pendapat anak, adalah asas yang memberikan hak kepada anak untuk menyatakan pendapat dalam segala hal yang mempengaruhi anak, meliputi: 1) hak untuk berpendapat dan memperoleh pertimbangan atas pendapatnya, b) hak untuk mendapat dan mengetahui informasi serta untuk mengeskpresikan, c) hak untuk berserikat menjalin hubungan untuk bergabung, dan d) hak untuk memperoleh informasi yang layak dan terlindung dari informasi yang tidak sehat.

Menurut Rika Saraswati, mmberikan perlindungan kepada anak merupakan tindakan yang tepat karena anak-anak dikategorikan sebagai kelompok yang rentan (vulnerable groups) di samping kelompok rentan lainnya, seperti pengungsi (refugees), pengungsi dalam negeri (internally displaced persons), kelompok minoritas dalaman (indigenous peoples), dan perempuan (women). Komite Perserikatan Bangsa-Bangsa untuk hak ekonomi, sosial, dan budaya juga mengidentifikasi anak-anak sebagai kelompok rentan bersama-sama dengan kelompok lainnya, seperti petani yang tidak memili tanah, pekerja di desa, pengangguran di desa, pengangguran di kota, kaum miskin kota, usia lanjut, dan kelompok khusus lainnya. Perlindungan terhadap anak menjadi sangat penting karena pelanggaran atas perlindungan anak pada hakikatnya merupakan pelanggaran terhadap hak asasi manusia. Selain itu, pelanggaran hak anak dapat menjadi penghalang sangat besar bagi kelansungan hidup dan perkembangan anak karena anak yang mengalami kekerasan, eksploitasi, pengabaian, dan perlakuan salah lainnya akan mengambil resiko, seperti hidup yang lebih pendek, memiliki kesehatan mental dan fisik buruk, mengalami masalah-masalah yang berkaitan dengan 
pendidikan (termasuk putus sekolah), memiliki ketrampilan yang buruk sebagai orang tua, menjadi tunawisma, terusir dari tempat tinggalnya, dan tidak memiliki rumah. Akan tetapi, di sisi lain, tindakan perlindungan yang sukses akan meningkatkan peluang anak untuk tumbuh sehat secara fisik, mental, percaya diri, dan memilki harga diri, dan kecil kemungkinan melakukan abuse atau eksploitasi terhadap orang lain, termasuk anaknya sendiri ${ }^{40}$.

Perlindungan terhadap anak yang berkelanjutan memang sangat diperlukan, karena banyak faktor yang menyebabkan anak berisiko mengalami kekerasan, pengabaian, eksploitasi, dan perlakuan salah lainnya, dimana penulis mencoba menguraikan perlindungan anak yang berkelanjutan ini disesuaikan dengan konsep Rika Saraswati yaitu ${ }^{41}$ :

a) Cara pengusahan mengunakan kekerasan yang diterapkan lintas generasi, pengasuhan demikian biasanya masih menggunakan pendekatan militer atau pendekatan otoriter. Jenis pengasuhan ini memberi pengalaman kepada anak tentang kekerasan. Setelah anak dewasa, ada kecenderungan ia akan menggunakan pendekatan yang sama. Di sisi lain, pengasuhan yang egaliter akan menumbuhan hubungan pertemanan orang tua dengan anak tanpa mengurangi nilai-nilai hormat antara kedua pihak;

b) Kemiskinan yang berdampak urbanisasi, perubahan gaya hidup, dan perubahan harapan terhadap kualitas hidup, kemiskinan sangat jelas telah menghambat kesempatan dan cita-cita anak untuk tumbuh dan berkembang sesuai dengan keinginannya. Pemerintahan yang tidak mampu memberi kesempatan kerja kepada para orang tua akan berdampak pada anak-anak, di antaranya, anak-anak berhenti sekolah karena tidak ada uang untuk membayar sekolah, sebab kepentingan perut lebih diutamakan dari pada sekolah. Setelah berhenti sekolah, anak-anak tidak mempunyai aktivitas lagi, sehingga mereka terdorong untuk bekerja membantu orang tuanya;

c) Nilai-nilai di masyarakat yang eksploitatif (nilai anak sebagai komoditas) dan diskriminatif, masih ada sebagian orang tua di masyarakat yang menganggap bahwa anak adalah hak miliknya, sehingga hak-hak anak cenderung diabaikan. Namun, di sisi lain, anak selalu dituntut untuk memenuhi kewajibannya,

${ }^{41}$ Ibid, hlm. 27-28. 
seperti harus menghormati rang tua, menurut segala perintah dan kehendak orang tua, serta tidak boleh membangkang. Begitu pula ketika anak berada di sekolah, anak harus menghormati, mematuhi perintah, dan kehendak guru. Hal ini menunjukkan bahwa anak sering dipandang sebagai kelompok yang tidak pernah dianggap secara sosial, kultural, atau secara legal. Akibatnya, anak menjadi rentan terhadap segala macam kekerasan (fisik, psikis, seksual, penelantaran, eksploitasi, diksriminasi, dan pelecehan) yang pada hakikatnya merupakan bentuk pelanggaran hak asasi manusia. Kekerasan terhadap anak dapat terjadi di ranah privat, seperti di dalam rumah tangga ataupun di ranah publik, seperti di sekolah dan di tempat umum lainnya;

d) Sistem hukum yang tidak mendukung perlindungan anak, meskipun Indonesia sudah memiliki berbagai aturan hukum yang mengatur tentang anak di berbagai bidang, pelaksanaan perlindungan hukum bagi anak masih sangat jauh dari harapan. Tidak hanya peraturan hukum tentang anak yang satu sama lain ada yang bertentangan, bahkan diperparah lagi oleh pihak aparat penegak hukum yang masih belum berspektif hak anak dalam menghadapi dan menyelesaikan persoalan. Selain itu, dukungan masyarakat atau budaya hukum masyarakat juga masih rendah, terutama dalam memosisikan seorang anak dan pengetahuan tentang hak-hak anak.

Atas dasar-dasar tersebut, sangat dibutuhkan kesadaran semua lapisan ataupun golongan yang berkaitan dengan perlindungan anak, karena tumbuh dan besarnya anak akan selalu berkaitan dengan pertanyaan, apakah perlindungan anak sudah berjalan di Indonesia? Dengan konsep perlindungan anak yang berekelanjutan menegaskan bahwa perlindungan anak tidak hanya berhenti dalam tataran undangundang saja, tetapi harus berimplikasi di dalam kehidupan nyata seorang anak. dari dia bangun tidur, bersekolah, bermain, belajar, makan dan minum, sampai dengan tidurnya serta terkait aktivitas lainnya yang berkaitan dengan tumbuh kembang serang anak.

\section{E. Penutup}

Orang tua sebagai orang yang pertama kali ditemui anak setelah melahirkan seyogyannya orang tua mendukung perlindungan anak. Anak akan bersama orang tua 
dari dalam kandungan sampai dengan besarnya nanti, anak selalu butuh perlindungan dan kasih sayang. Orang tua yang menelantarkan dan tidak mau melindungi anak, akan menciptakan anak yang tidak baik nantinya, karena akan banyak menyusahakan masyarakat. Maka dari pada itu perlindungana adalah suatu hukum yang wajib untuk dipenuhi oleh orang tua. Perlindungan Anak merupakan bagian dari Hak Asasi Manusia, jika perlindungan anak tidak diberikan rang tua maka orang tua sama saja membuat pelanggaran terhadap Hak Asasi Manusia. Tentu saja pelanggaran ini akan memiliki implikasi hukum di kemudian hari. Terhadap partispasi orang tua terhadap perlindungan anak dapat kita temui dalam Undang-Undag Nomor 35 Tahun 2014 tentang Perubahan Atas Undang-Undang Nomor 23 Tahun 2002 tentang Perlindungan Anak serta Undang-Undang Nomor 1 Tahun 1974 Tentang Perkawinan. Di dalam undang-undang itu dijelaskan bagaimana peran orang tua dalam berpartispasi memberikan perlindungan yang terbaik bagi anak, maka dari itu penulis mencoba menawarkan konsep perlindungan anak yang berkelanjutan. Konsep perlindungan anak sangat dibuthkan sekali di dalam mengawal pelindungan anak, karena dengan konsep perlindungan ini memberikan ketegasan bahwa perlindungan harus benar-benar dijalankan di dalam lapangan, dan bukan hanya sampai dalam sebatas aturan saja, yaitu Undang-Undang Perlindungan Anak. 


\section{DAFTAR PUSTAKA}

\section{Buku}

Abdul Garuda Hakim Nusantara dan Nasroen Yasabari, 1980, Beberapa Pembangunan Hukum Di Indonesia, Bandung, Alumni.

Amirudin, Zainal Asikin, Pengantar Metode Penelitian Hukum, Jakarta, Raja Grafindo, 2012.

Bambang Waluyo, Penelitian Hukum Dalam Praktek, Jakarta, Sinar Grafika, 2008.

Gunawan Setiadirdja, 1993, Hak-hak Asasi Manusia Berdasarkan Ideologi Pancasila, Jakarta, Penerbit Kanisius.

H. A. Prayitno dan Trubus Rahardiansah P, 2013, Pendidikan Kadeham, Kebangsaan, Demokrasi dan Hak Asasi Manusia, Menapak Jejak-Jejak Reformasi, Jakarta, Penerbit Universitas Trisakti.

Irma Setyowati Soemitro, 1990, Aspek. Hukum Perlindungan Anak, Jakarta, Bumi Aksara.

Johnny Ibrahim, 2006, Teori dan Metodologi Penelitian Hukum Normatif, Jawa Timur, Bayu Media Publishing.

Kepolisan Republik Indonesia, 2006, Buku Panduan Tentang Hak Asasi Manusia Untuk. Angoota Polri, Jakarta.

Krisna Harahap, 2003, HAM dan Upaya Penegakannya Di Indonesia, Jakarta, PT Grafitri Budi Utama.

Maidin Gultom, 2012, Perlindungan Hukum Terhadap Anak dan Perempuan, Bandung, Refika Aditama.

2014, Perlindungan Hukum Terhadap Anak dalam Sistem Peradilan Pidana Anak di Indonesia, Bandung, Refika Aditama

Marnasse Malo dan Sri Trisnongtias, 1997, Metode Penelitian Masyarakat, Jakarta, Pusat Antara Universitas Ilmu-Ilmu Sosial Unversitas Indonesia.

Otong Rosadi, 2004, Hak Anak Bagian Dari HAM, Bandung, Akademika.

Rahayu, 2012, Hukum Hak Asasi Manusia (HAM), Semarang, Badan Penerbit Universitas Diponegoro.

Rika Saraswati, 2015, Hukum Perlindungan Anak Di Indonesia, Bandung, Citra Aditya Bakti.

R. Abdussalam, 2007, Hukum Perlindungan Anak, Jakarta, Restu Agung. dan Adri Desasfuryanto, 2007, Hukum Perlindungan Anak, Jakarta, PTIK.

Satjipto Raharjo, 1986, Ilmu Hukum, Bandung, Alumni Bandung.

Satya Arinanto, 2001, Bahan Bacaan Politik. Hukum 2, Jakarta, Program Pasca Sarjana FHUI.

Scott Davidson, 1994, Hak Asasi Manusia, Sejarah, Teori dan Praktek dalam Pergaulan Internasional, Jakarta, Grafiti.

Setiono, Rule of Law (Supremasi Hukum), (Surakarta: Magister Ilmu Hukum Program Pasca Sarjana Universitas Sebelas Maret, 2004), hlm. 3, dikutip dalam (http://digilib.unila.ac.id/6225/13/BAB\%20II.pdf). Diakses 5 oktober 2015.

H. Salim HS dan Erlies Septiana N, Penerapan teori bukum pada Penelitian Tesis dan Disertasi, Rajawali Pers, Jakarta, 2014, cet 3.

Philipus M. Hadjon, Perlindungan bukum bagi rakyat Indonesia, sebuah studi tentang prinsip prinsip penanganan oleh pengadilan dalam lingkungan peradilan umum dan pembentukan peradilan administrasi, Fakultas Hukum Universitas Airlangga, Surabaya, 1985 
Siska Lis Sulistiani, 2015, Kedudukan Hukum Anak, Hasil Perkawinan Beda Agama Menurut Hukum Positif dan Hukum Islam, Bandung, Refika Aditama

Todung Mulya Lubis, 1993, In search of Human Rights Legal-Political Dilemmas of Indonesia's New Order, 1966-1990, S.J.D Dissertaion, (Berkeley: Boalt Hlml Law School - University of California, 1990).

Wagiati Soeteddjo dan Melani, 2011, Hukum Pidana Anak, Bandung, Refika Aditama. Zainuddin Ali, 2010, Metode Penelitian Hukum, Jakarta, Sinar Grafika.

Jurnal

Yuliandri, Membentuk Undang-Undang Yang Berkelanjutan, Jurnal Konstitusi, Vol. II No 2, (2009).

\section{Perundang-Undangan}

Undang-Undang Dasar Negara Kesatuan Republik Indonesia Tahun 1945

Undang-Undang Nomor 1 Tahun 1974 Tentang Perkawinan

Undang-Undang Nomor 39 Tahun 1999 Tentang Hak Asasi Manusia

Undang-Undang Nomor 35 Tahun 2014 Tentang Perubahan Atas Undang-Undang Nomor 23 Tahun 2002 Tentang Perlindunga Anak. 